\title{
INOVASI KEBIJAKAN PUBLIK DALAM PENGEMBANGAN BADAN USAHA MILIK DESA
}

\author{
Sutri Destemi Elsi, ${ }^{1}$ Faizah Bafadhal, ${ }^{2}$ dan Rahman Ahmad ${ }^{3}$ \\ ${ }^{1,2}$ Prodi Ilmu Politik, FISIP, Universitas Jambi, Mendalo Indah, Jambi \\ ${ }^{3}$ Prodi Ilmu Hukum, FH, Universitas Adiwangsa Jambi, Jambi
}

\begin{abstract}
This study describes and analyzes the innovation of policies and public services of the Village Government of Tanjung continued, Muaro Jambi Regency, especially in the development of BUMDes so that they can move the wheels of the community's economy. Public policy innovation is a necessity that must be done to overcome problems that exist in society. From the point of view of the study of public policy policies and public services, it can be seen that the Village Government of Tanjung continued has developed several BUMDes development strategies that have led this village to become a pilot village in Muaro Jambi Regency even though it had to face various obstacles. However, the concept of obstacles will give birth to a new concept in the policy process and public services.
\end{abstract}

\begin{abstract}
Abstrak: Penelitian ini mendeskripsikan serta menganalisis inovasi kebijakan dan pelayanan publik Pemerintah Desa Tanjung Lanjut Kabupaten Muaro Jambi khususnya dalam pengembangan BUMDes sehingga dapat menggerakkan roda perekonomian masyarakat. Inovasi kebijakan publik adalah sebuah keniscayaan yang harus dilakukan untuk mengatasi problematika yang hadir di tengah masyarakat. Dalam sudut pandang kajian kebijakan publik dan pelayanan publik dapat tergambar bahwa Pemerintah Desa Tanjung Lanjut telah mengembangkan beberapa strategi pengembangan BUMDes yang mengantarkan desa ini menjadi desa percontohan di Kabupaten Muaro Jambi meskipun harus menghadapi berbagai hambatan. Namun demikian pada dasarnya hambatan itu akan melahirkan sebuah konsep baru dalam proses kebijakan dan pelayanan publik.
\end{abstract}

Kata kunci: inovasi kebijakan, pelayanan publik, BUMDes, Desa Tanjung Lanjut

\section{PENDAHULUAN}

Kemajuan ekonomi nasional hanya akan tercapai jika terdapat iklim perekonomian yang baik di tingkat provinsi. Kemajuan ekonomi di tingkat provinsi akan tercapai jika kabupaten memiliki kegiatan ekonomi yang baik. Kemajuan ekonomi sebuah kabupaten dapat tercapai karena adanya sumbangsih dari ekonomi pedesaan yang kuat yang berimbas pada kesejahteraan masyarakat luas. Hal ini akan menjamin penyelenggaraan pemerintahan yang baik untuk diterapkan di semua tingkat pembangunan dan keputusan berdasarkan kebutuhan nyata dari masyarakat. Pembangunan pedesaan merupakan salah satu cara dalam upaya mengentaskan kemiskinan

Pengembangan basis ekonomi di pedesaan sudah semenjak lama dijalankan oleh pemerintah melalui berbagai program. Namun upaya itu belum membuahkan hasil yang memuaskan sebagaimana diinginkan bersama. Salah satu faktor yang paling dominan adalah intervensi pemerintah terlalu besar, akibatnya justru menghambat daya kreativitas dan inovasi masyarakat desa dalam mengelola dan menjalankan mesin ekonomi di pedesaan. Sistem dan mekanisme kelembagaan ekonomi di pedesaan tidak berjalan efektif dan berimplikasi pada ketergantungan terhadap bantuan pemerintah sehingga mematikan semangat kemandirian.

Berdasarkan asumsi itu maka sudah seharusnya eksistensi desa mendapatkan perhatian yang serius dari pemerintah pusat dengan lahimya kebijakan-kebijakan terkait dengan pemberdayaan ekonomi yang dilakukan dengan cara menghimpun dan melembagakan kegiatan ekonomi masyarakat. Oleh karena itu, pemerintah menerapkan pendekatan baru yang diharapkan mampu menstimulus dan menggerakkan roda perekonomian di pedesaan adalah melalui pendirian kelembagaan ekonomi yang dikelola sepenuhnya oleh masyarakat desa, yaitu Badan Usaha Milik Desa.

BUMDes pada dasarnya merupakan pilar kegiatan ekonomi di desa yang berfungsi sebagai lembaga sosial (social institution) dan komersial (commercial institution). BUMDes sebagai 
lembaga sosial harus berpihak kepada kepentingan masyarakat melalui kontribusinya dalam penyediaan pelayanan sosial. Hal ini sesuai dengan tujuan pendirian sebuah BUMDes pada umumnya, yaitu: (1) Meningkatkan Perekonomian Desa, (2) Meningkatkan Pendapatan asli Desa, (3) Meningkatkan Pengelolaan potensi desa sesuai dengan kebutuhan masyarakat, dan (4) Menjadi tulang punggung pertumbuhan dan pemerataan ekonomi desa.

Empat tujuan pendirian BUMDes itu sudah seharusnya melekat pada visi-misi sebuah pemerintahan desa. Keempat tujuan itu seharusnya menjadi sikap dan dedikasi semua Kepala Desa dan perangkatnya. Kepala Desa dan perangkatnya harus mampu berinovasi dalam membuat arah kebijakan pengembangan perekonomian dan peningkatan pelayanan terhadap masyarakat, dengan demikian proses peningkatan pembangunan yang diharapkan pemerintah dapat dimulai dari pinggiran (desa) dapat terlaksana karena didukung oleh kreatifitas dan partisipasi seluruh masyarakat. BUMDes lahir sebagai suatu pendekatan baru dalam usaha peningkatan ekonomi desa berdasarkan kebutuhan dan potensi desa. Pengelolaan BUMDES sepenuhnya dilaksanakan oleh masyarakat desa, yaitu dari desa, oleh desa, dan untuk desa.

Cara kerja BUMDes adalah dengan jalan menampung kegiatan-kegiatan ekonomi masyarakat dalam sebuah bentuk kelembagaan atau badan usaha yang dikelola secara profesional, namun tetap bersandar pada potensi asli desa. Hal ini dapat menjadikan usaha masyarakat lebih produktif dan efektif. Kedepan BUMDes akan berfungsi sebagai pilar kemandirian bangsa yang sekaligus menjadi lembaga yang menampung kegiatan ekonomi masyarakat yang berkembang menurut ciri khas desa dalam rangka meningkatkan kesejahteraan masyarakat desa. BUMDes lahir sebagai suatu pendekatan baru dalam usaha peningkatan ekonomi desa berdasarkan kebutuhan dan potensi desa. Pengelolaan BUMDes sepenuhnya dilaksanakan oleh masyarakat desa, yaitu dari desa, oleh desa, dan untuk desa.

BUMDes yang sukses yang dapat menjadi percontohan terutama di Kabupaten Muaro Jambi Provinsi Jambi adalah BUMDes Tanjung Lanjut
Kecamatan Sekernan Kabupaten Muaro Jambi. Badan Usaha Milik Desa (BUMDes) yang dinamai BUMDes Tanjung Jaya Mandiri didirikan melalui musyawarah desa pada tanggal 13 Juli 2015. Pendapatan Asli Desa (PAD) yang disetorkan BUMDes Tanjung Jaya Mandiri ke Pemerintah Desa sebesar Rp. 3.303 .000 (2016), Rp. 23.979.600 (2017) Rp. 27.101.800 (2018).

BUMDes yang dinamai Tanjung Jaya Mandiri ini berhasil membangun 6 (enam) unit badan usaha dengan menggandeng mitra-mitra strategis yang mereka miliki. BUMDes Tanjung Jaya Mandiri di Desa Tanjung Lanjut Kecamatan Sekernan Kabupaten Muaro Jambi beberapa kali terpilih sebagai BUMDes terbaik di Kabupaten Muaro Jambi karena mereka pelopor penggerak pendirian BUMDes, BUMDes Tanjung Jaya Mandiri baru-baru ini bekerja sama dengan beberapa Pemerintahan Desa dalam usaha pengolahan Wisata Air Danau Tangkas. BUMDes Tanjung Jaya Mandiri dalam hal ini menjadi pelopor pengerak perekonomian dari warga desa. Jenis usaha yang dijalankan sebagai berikut:

1. Perkebunan Kelapa Sawit (2016)

2. Simpan Pinjam (2016)

3. Bengkel Las (2016)

4. Perlengkapan Alat Pesta Orkes Musik (2017)

5. Wisata Desa Danau Tangkas (2018)

6. Pasar Desa

Sesuai dengan Visi dan Misi Desa Tanjung Lanjut yaitu salah satunya untuk "Mewujudkan masyarakat Desa Tanjung Lanjut yang mandiri, kreatif dan inovatif serta "Menumbuh-kembangkan kepedulian masyarakat dalam hal ilmu pengetahuan dan teknologi serta ekonomi kerakyatan", maka dapat dilihat Pemerintah Desa telah berupaya untuk melakukan inovasi dalam kebijakan dan peningkatan pelayan terhadap masyarakat melalui unit usaha yang telah dibentuk.

Di dalam anggaran dasar desa juga dijelaskan ada upaya sistematis untuk mendorong organisasi ini agar mampu mengelola aset ekonomi strategis di desa sekaligus mengembangkan jaringan ekonomi demi meningkatkan daya saing ekonomi pedesaan. Adapun tujuan pendirikan BUMDes Tanjung Jaya Mandiri adalah upaya penggalian pendapatan asli desa, menampung berbagai jenis usaha perekonomian di desa dan 
pemberdayaan ekonomi masyarakat desa. Oleh sebab itu, penting untuk menjadi catatan agar inovasi kebijakan dan pelayan publik yang telah dilakukan oleh Pemerintah Desa Tanjung Lanjut ini dapat terus dikembangkan serta didukung oleh semua lapisan masyarakat dan pemerintah daerah, karena semangat ini harus dapat ditularkan kepada desa-desa lain yang ada di Indonesia khususnya di Provinsi Jambi.

\section{METODE}

Penelitian ini merupakan penelitian yang bersifat kualitatif. Dalam penelitian kualitatif ini, metode yang dilakukan adalah dengan mengumpulkan data-data yang berasal dari berbagai literatur, dokumentasi atau wawancara yang dilakukan kepada sumber utama terkait dengan cara menganalisis antara konsep, kebijakan dan hasil yang ditemukan di lapangan saat dilakukannya penelitian. Data dan analisis yang akan menjadi bagian dari hasil kajian ini diperoleh dengan metode kajian pustaka (literary studies) dan diskusi terbatas. Kajian pustaka dilakukan dengan mempelajari undang-undang, juga berbagai artikel dan tulisan yang membahas mengenai isu tersebut. Sementara diskusi terbatas dilakukan untuk mendapatkan data primer yang relevan.

\section{HASIL DAN PEMBAHASAN}

Seiring dengan meningkatnya pemikiran kritis publik, maka publik kemudian sering menemukan indikasi yang menunjukan bahwa proses pembuatan kebijakan publik tidak inovatif, terutama terjadi karena orientasi kepentingan yang berbeda antara kepentingan pemerintah dengan kepentingan publik. Harus ada upaya terobosan yang dilakukan oleh pemerintah untuk mendeteksi aspirasi publik secara lebih cermat dan akurat. Sekurangnya harus ada second opinion ketika pemerintah menerima sejumlah aspirasi dari saluran resmi. Terutama harus tumbuh kesadaran dari pemerintah bahwa saluran aspirasi resmi yang selama ini bertugas menjaring aspirasi publik, ternyata kurang efektif sebab selalu menggunakan ukuran normatif dan formalistik, alias bekerja secara tidak membumi, tidak langsung bersandar kepada denyut kepentingan publik yang sesungguhnya.

Pelayanan publik yang baik dan berkualitas merupakan hak warga negara sekaligus kewajiban konstitusional negara. Oleh karenanya pemerintah wajib hukumnya menyelenggarakan pelayanan publik yang sebaik-baiknya kepada masyarakat. Peningkatan pelayanan publik saat ini dibandingkan dengan harapan masyarakat diilustrasikan antara deret hitung berbanding deret ukur. Kemajuan pelayanan publik yang berjalan seperti deret hitung akan semakin jauh ketinggalan dari harapan masyarakat yang melompat seperti deret ukur. Inovasi pelayanan publik merupakan percepatan membuat lompatan terobosan untuk menjadi solusi peningkatan kualitas pelayanan publik yang lebih mendekatkan dengan harapan masyarakat.

Dalam pemberdayaan masyarakat di bidang sektor perekonomian memerlukan strategi pengembangan usaha. Badan Usaha Milik Desa selanjutnya disingkat dengan BUMDes diproyeksikan muncul sebagai kekuatan ekonomi baru di wilayah perdesaan. UU No 6 tahun 2014 tentang Desa memberikan payung hukum atas BUMDes sebagai pelaku ekonomi yang mengelola potensi desa secara kolektif untuk meningkatkan kesejahteraan warga desa. Ada yang menjalankan bisnis simpan-pinjam (keuangan mikro), ada juga yang menyelenggarakan pelayanan air minum untuk mengatasi kesulitan akses masyarakat terhadap air bersih. Police Paper Forum Pengembangan Pembaharuan Desa (FPPD) yang ditulis oleh Yunanto dkk (2014) menjelaskan ada sejumlah kelemahan yang secara inheren ada pada BUMDes, yaitu:

1) Penataan kelembagaan desa belum berjalan secara maksimal sehingga BUMDes pun belum dilembagakan dalam format kepemerintahan dan perekonomian desa.

2) Keterbatasan kapasitas sumber daya manusia di desa untuk mengelola dan mengembangkan BUMDes yang akuntabel dan berkinerja baik.

3) Rendahnya inisiatif lokal untuk menggerakkan potensi ekonomi lokal bagi peningkatan kesejahteraan sosial dan ekonomi warga desa. 4) Belum berkembangnya proses konsolidasi 
dan kerjasama antar pihak terkait untuk mewujudkan BUMDes sebagai patron ekonomi yang berperan memajukan ekonomi kerakyatan.

5) Kurangnya responsivitas Pemda untuk menjadikan BUMDes sebagai program unggulan untuk memberdayakan desa dan kesejahteraan masyarakat.

Aksa (2013) menjelaskan ada empat jenis bisnis yang bisa dikembangkan oleh BUMDes, antara lain:

1) BUMDes yang bertipe serving. BUMDes semacam ini menjalankan bisnis sosial yang melayani, yaitu melakukan pelayanan publik kepada masyarakat sekaligus juga memperoleh keuntungan finansial dari pelayanan itu. Usaha ini memanfaatkan sumber daya lokal dan teknologi tepat guna, seperti usaha air minum desa dan usaha listrik desa.

2) BUMDes yang bertipe banking. BUMDes ini menjalankan bisnis uang seperti bank desa atau lembaga perkreditan desa. Modalnya berasal dari ADD, PADes, tabungan masyarakat serta dukungan dari pemerintah. Bisnis uang desa ini mengandung bisnis sosial dan bisnis ekonomi. Bisnis sosial artinya bank desa merupakan proteksi sosial terhadap warga desa, terutama kelompok warga yang rentan dan perempuan dari jeratan para rentenir. Bisnis ekonomi artinya bank desa berfungsi untuk mendukung permodalan usaha-usaha skala mikro yang dijalankan oleh pelaku ekonomi di desa.

3) BUMDes bertipe renting. BUMDes ini menjalankan bisnis penyewaan barang-barang (perangkat pesta, traktor, alat transportasi, ruko, dan lain sebagainya), baik untuk memenuhi kebutuhan masyarakat maupun untuk memperoleh pendapatan desa.

4) BUMDes bertipe brokering. BUMDes ini berperan sebagai lembaga perantara, seperti jasa pelayanan kepada warga maupun usahausaha masyarakat, misalnya jasa pembayaran listrik, desa mendirikan pasar desa untuk memasarkan produk-produk yang dihasilkan masyarakat. BUMDes juga bisa membangun jaringan dengan pihak ketiga untuk memasarkan produk-produklokal secara lebih luas.
Salah satu BUMDes yang dapat menjadi rujukan dan percontohan di Provinsi Jambi adalah BUMDes Tanjung Jaya Mandiri yang terdapat di desa Tanjung Lanjut. BUMDes Tanjung Jaya Mandiri dalam hal ini menjadi pelopor pengerak perekonomian bagi warga desa. Terdapat 6(enam) jenis usaha yang dijalankan oleh BUMDes sebagai berikut:

1) Perkebunan Kelapa Sawit (2016)

2) Simpan Pinjam (2016)

3) Bengkel Las (2016)

4) Sewa Perlengkapan Alat Pesta Orkes Musik (2017)

5) Wisata Desa Danau Tangkas (2018)

6) Pasar Desa

Hadirnya BUMDes ini tentu tidak terlepas dari adanya inovasi serta upaya yang dikembangkan oleh pemerintah desa serta didukung oleh masyarakatnya. Pembentukan BUMDes ini juga tidak serta merta terbangun dalam waktu yang singkat namun melalui proses dan waktu yang terus berkesinambungan melewati berbagai rintangan. Oleh sebab itu pemerintah desa harus selalu giat melakukan inovasi dalam mengembangkan BUMDes agar benar-benar dapat menjadi penggerak roda perekonomian masyarakat.

Pemerintah desa harus memiliki strategi pengembangan BUMDes-nya. Dalam hal ini desa Tanjung Lanjut telah berupaya konsisten dalam upaya meningkatkan kesejahteraan masyarakat melalui BUMDes, beberapa langkah strategi disampaikan Tutur Saprudin dapat tergambar sebagai berikut:

1) Perumusan strategi, dalam hal ini BUMDes Tanjung Jaya Mandiri melakukan perencanaan dalam membuat misi, tujuan dan strategi.

2) Pemetaan potensi desa untuk pendirian dan pengembangan BUMDes.

3) Menjalin kerjasama dengan intansi Pemerintahan Daerah Kabupaten Muaro Jambi Maupun Provinsi Jambi dalam pembinaan maupun permodalan;

4) Menjalin kerjasama dengan swasta untuk ikut serta dalam mengakses investasi dan pengembangan teknologi dalam promosi dalam unit usaha Desa Wisata Danau Tangkas;

5) Memberikan pinjaman dengan bunga yang 
rendah untuk setiap usaha dibantu dengan permodalan tanpa adanya jaminan.

6) Melibatkan masyarakat dalam pengelolaan dan pemanfaatan BUMDes.

7) Membentuk BUMDes bersama sama dengan beberapa desa tetangga dalam mengembangkan Unit usaha serta memperkuat permodalan dan pengelolaan;

8) Evaluasi dan pengendalian, pada tahap ini BUMDes melakukan penyerahan laporan setiap unit usaha yang dijalankan agar setiap kegiatan yang berlansung dapat selalu diawasi dan ditinjau serta perlunya evaluasi/perbaikan-perbaikandalam menjalankanBUMDes.

Berbagai strategi yang telah dikebangkan pada perkembangannya telah mampu merubah kondisi sosial dan ekonomi masyarakat meskipun masih dihadapkan dengan berbagai tantangan. Perubahan itu dapat tercermin dari meningkatnya partisipasi masyarakat dalam pemanfaatan BUMDes, selain itu kehadiran BUMDes ini dinilai sebagai sebuah prestasi khususnya bagi Kabupaten Muaro Jambi. Desa ini menjadi desa percontohan untuk pertumbuhan dan pengelolaan desa melalui BUMDes. Upaya-upaya untuk terus meningkatkan serta memaksimalkan terus menerus dilakukan oleh desa melalui aparat pemerintah desa.

Seiring dengan tuntutan inovasi untuk perbaikan dan peningkatan kondisi sosial dan ekonomi desa kepada pemerintah desa, tentunya tidak terlepas dari hambatan terhadap inovasi itu sendiri, demikian juga hal nya dalam upaya pengelolaan dan pengembangan BUMDes di Desa Tanjung Lanjut. Ada beberapa faktor yang seringkali menjadi penghambat :

1) Akses jalan menuju lokasi desa belum memadai, sehingga daya tarik pengunjung untuk datang melihat objek wisata Danau tangkas menjadi lemah dan pengunjung menjadi tidak tertarik untuk berwiasata ke Danau Tangkas.

2) Kurangnya promosi yang dilakukan oleh pengurus dan tidak responsifnya pemerintahan daerah dalam mengembangkan potensi Desa wisata yang ada di daerah Muaro Jambi.

3) Regulasi yang belum memadai secara terstruktur dari pemerintah pusat dan daerah.

4) Terbatasnya dana untuk pengambangan
BUMDes.

5) Kondisi masyarakat yang sulit menerima perubahan.

Menyikapai berbagai hambatan tersebut pemerintah desa Tanjung Lanjut tetap konsisten untuk terus melanjutkan strategi yang telah disusun untuk pengembangan BUMDes, karena setiap kebijakan publik pada dasarnya akan selalu memberikan umpan balik untuk lahirnya kebijakan baru yang lebih inovatif.

\section{SIMPULAN}

Pengelolaan BUMDes harus terus menerus dilakukan dengan melahirkan inovasi dan terobosan baru baik dalam kebijakan maupun dalam penerapan pelayanan publik terhadap masyarakat. Telah menjadi keharusan bagi pemerintah daerah khususnya pemerintah desa untuk terus berupaya menggerakkan perekonomian masyarakat guna peningkatan pendapatan masyarakat khususnya dan desa pada umumnya. Akan tetapi upaya itu juga harus didudukung secara maksimal oleh masyarakat dengan turut berpartisipasi aktif dalam pengelolaan dan pemanfaatan BUMDes.

\section{DAFTAR PUSTAKA}

Agunggunanto,dkk.2016. Pengembangan Desa Mandiri Melalui Pengelolaan Badan Usaha Milik Desa (BUMDes), Jurnal Dinamika Ekonomi dan Bisnis. 3(1): 1-10.

Aqmarina. 2017. Keberadaan Badan Usaha MilikDesa(Bumdes) terhadap Kesejahteraan Masyarakat Desa Ponggok, Kecamatan Polanharjo, Kabupaten Klaten, Provinsi Jawa Tengah. Skripsi Fakultas Ekonomi dan Bisnis Universitas Diponegoro. Semarang.

Alkadafi. 2014. Penguatan Ekonomi Masyarakat Melalui Pengelolaan Kelembagaan Badan Usaha Milik Desa Menuju Asean Economic Community 2015. Jurnal ElRiyasah, 1(1): 1-15.

Atik \& Ratminto. 2005. Manajemen Pelayanan:

Disertai dengan Pengembangan Model Konseptual, Penerapan Citizen's Charter san Standar Pelayanan Minimal. Yogyakarta: Pustaka Pelajar 
Dunn, William N., 2000, Pengantar Analisis Kebijakan Publik, Yogyakarta: Gadjah Mada University Press.

E. Koswara, 2002, Otonomi Daerah, Untuk Demokrasi dan Kemandirian Rakyat, Jakarta: Candi Cipta Paramuda.

Friedrick, Carl J., 1963, Man and His Government, New York: McGraw Hill.

Hardiyansyah, 2011. Kualitas Pelayanan Publik Konsep, Dimensi, Indikator dan Implementasinya. Yogyakarta: Gava Media.

Leo, Agustino, 2006, Politik dan Kebijakan Publik, Bandung: AIPI Bandung.

Luankali, Perbadus, 2007, Analisis Kebijakan dalam Proses Pengambilan Keputusan, IPDN Depdagri.
Pusat Kajian Dinamika Sistem Pembangunan. 2007. Buku Panduan Pendirian dan Pengelolaan Badan Usaha Milik Desa. Departemen Pendidikan Nasional. Fakultas Ekonomi. Universitas Brawijaya.

Sinambela, Lijan Poltak. dkk, 2011 Reformasi Pelayanan Publik. Jakarta:Bumi Aksara Suharno. 2010, Dasar-dasar Kebijakan Publik (Kajian Proses dan Analisis Kebijakan). Yogyakarta: UNY Press.

Suharto, Edi, 2005, Analisis Kebijakan Publik, Bandung: Alfabeta.

Umi Hidayati, dkk. 2015. Analysis of Education and Training Needs To Increase BUMDes ManagementCapacityin Developing Business Units. Jurnal Bisnis dan Manajemen. 7 (23): 1-20. 